\title{
UK nuclear waste firm faces US critics
}

[WASHINGTON] A top official of BNFL, the UK-based nuclear-fuels corporation, told a congressional hearing last week that the company is ready to tackle the waste left behind from the plutonium production that sustained the US nuclear arsenal during the Cold War.

BNFL is confident it can vitrify ten per cent of the 54 million gallons of liquid, solid and sludge waste held in 177 underground tanks at Hanford in Washington state, the ugliest nuclear waste problem in the United States. "There's no question that this can be done," says Tom Crimmins, BNFL's US chief executive officer.

But the contract proposed by the Department of Energy (DoE) with BNFL was criticized at a hearing of the oversight subcommittee of the House Commerce Committee for leaving too much risk with government. The contract specifies that BNFL will design and build waste treatment and vitrification plants at Hanford to begin operation by 2007.

Despite the DoE describing the contract as a "privatization" of the Hanford waste problem, it was criticized by Joe Barton (Republican, Texas), chair of the subcommittee.

Barton said that BNFL would commit $\$ 300$ million to the project but receive $\$ 1.8$ billion in profits and fees. He promised that Congress will monitor the contract closely.

BNFL was left as the sole candidate after a rival contractor, Lockheed, was rejected by the DoE in May on technical grounds.

In August, the DoE signed a contract with BNFL to process ten per cent of the waste by 2017 for $\$ 6.9$ billion. This price will be reviewed in two years, by which time BNFL is due to have built a pilot $\$ 25$ million waste treatment facility and completed 30 per cent of the plant's design work.

BNFL will borrow capital from the private sector to build the vitrification plant, then DoE will pay it to vitrify the waste. Critics, including some environmentalists, say this is a false economy, as the DoE is liable for BNFL's debts if the contract is not completed.

A report from the General Accounting
Office last week said "DoE's financial risks are significant", and doubted that the department could adequately oversee the project.

But some critics go further. Gerald Pollet, director of the environmental group Heart of America Northwest, told the hearing the government could save $\$ 3$ billion by contracting on a conventional, fixed-price basis.

But Crimmins says BNFL will carry the risk of cost overruns. He is backed up by the energy undersecretary Ernie Moniz, who says: "There's plenty of risk for the contractor - their equity is first in line."

As well as the Hanford contract, BNFL is leading a consortium that hopes to take over the nuclear operations of Westinghouse, including management of the Savannah River site in South Carolina.

Environmental groups have criticized BNFL for its allegedly secretive culture and its track record on health and safety in Britain. But no one at the hearing objected to these or the fact that it is publicly owned by the British government.

ColinMacilwain

\section{Epidemiologist's funds axed after report on Californian smoking}

[SAN FRANCISCO] The state of California's decision to stop funding an epidemiologist, following a dispute over his report on smoking behaviour, has prompted concern about the state's apparent reluctance to accept unfavourable scientific results.

John Pierce, an epidemiologist at the University of California, San Diego, who has conducted three surveys on smoking for the California Department of Health Services during the past decade, has had his contract abruptly discontinued after a dispute over both his methodology and his findings.

Pierce had been sent a letter in December confirming the agency's intention to extend his contract up to the year 2000 for $\$ 4.85$ million. He was asked to assess adolescent smoking, complete a fourth survey on smoking behaviour in the state, and report on the success of a state tobacco control programme funded by a cigarette tax of 25 cents a pack introduced in 1990.

But after months of wrangling over Pierce's 1996 final report, the department accepted his results, but ended his contract.

The report, available on the World-Wide Web (ssdc.ucsd.edu/tobacco/reports), concludes that the tobacco control programme lost its effectiveness, and a downward trend in smoking rates ended, in 1994, the year state legislature cut spending on anti-smoking campaigns by 40 per cent. It also predicts that smoking in young people is likely to have increased by 14 per cent between 1996 and 1999.

Donald Lyman, chief of the Division of

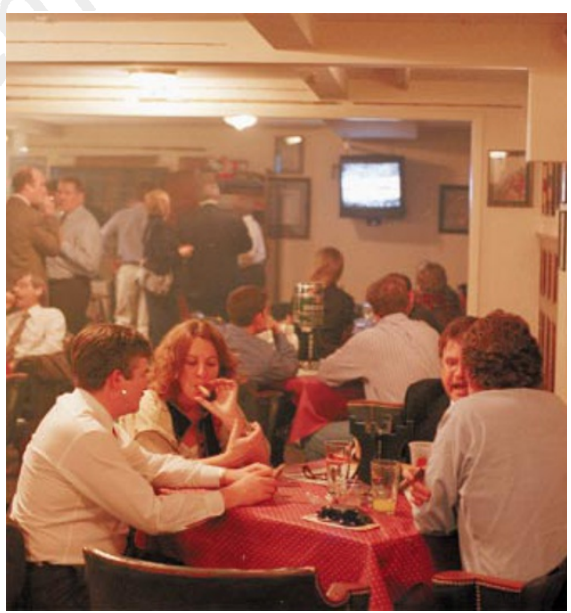

Smoke-filled rooms: California's crackdown on smoking has led to the rise of smoking clubs.

Chronic Disease and Injury Control, says that, in an environment already strained by an anxious state administration and a hostile tobacco industry, Pierce had become impossible to work with.

But Pierce and other researchers claim the department's action was intended to prevent the publication of data that highlight the harm caused to smokingprevention efforts by state funding cuts.

"He produced results [that were] not politically acceptable and got fired for it," says Stanton Glantz, a tobacco researcher and professor of medicine at the University of California, San Francisco. He calls the decision "outrageous and appalling".
State health department officials say that, among other weaknesses, the analysis relies on questionable statistical models and incorporates a problematic definition of individuals who smoke less than 100 cigarettes a year.

But Pierce argues that the methodological adjustments he was asked to make would have altered the results and created a continuing downward trend in smoking rates. He did make some of the changes, but told the department that the others would damage the scientific credibility of the report.

"We felt we'd bent over backwards to be responsive to comments," says Pierce. He says he thinks the department was concerned about his report's clear documentation of the effect of funding cuts and so decided not to renew his contract.

Joel Moskowitz, deputy director of the Center for Family and Community Health at the University of California, Berkeley, says there is merit to the department's concerns. He criticizes several aspects of Pierce's results and analysis.

But Moskowitz says he has no doubt that the state axed Pierce for political reasons after he refused to make the proposed changes. Moskowitz suggests this reflects problems throughout the state, where the agency that is funded to carry out a programme is also asked to evaluate it.

But Lyman denies that the non-renewal of Pierce's contract was intended to penalize him for bringing bad news. Sally Lehrmann 